\title{
Investment Decision, Capital Decision, Industry Performance, Econimic Macros as Antecedent Variables of Financial Risk Management and Financial Distress Against Value of The Firm With GCG As a Variable Moderating For Manufacturing Companies Registered On The indonesian stock exchange.
}

\author{
Ulfi Pristiana \\ Doctoral Student at The Doctoral Program in The Faculty of Economics and Business at The \\ University of 17 Agustus 1945 Surabaya, Indonesia \\ Department of Management, The Faculty of Economics and Business at The University of 17 \\ Agustus 1945 Surabaya, Indonesia \\ Tri Ratnawati \\ Lecturer at The Faculty of Economics and Business at The University of \\ 17 Agustus 1945 Surabaya, Indonesia \\ Andre Dwijanto Witjaksono \\ Lecturer at The Faculty of Economics \\ at The Surabaya State University, Indonesia
}

\begin{abstract}
The purpose of this study is to analyze and prove the effect of Investment Decision, Capital Decision, Industry Performance, Macro Economic As Antecedent Variables of Financial Risk Management And Financial Distress To Value Of The Firm With GCG As Moderating Variables. The population of this study is manufacturing companies listed on the BEI from 2014 to 2016 . Using the method of purposive sampling it was found 40 manufacturing companies as research samples. The result of this research shows that Investment Decision, Capital Decision, Industry Performance, Macro Economic, Financial Distress and GCG have significant influence to the company value of the firm , but Financial Risk Management has no significant influence to company value of the firm . GCG moderates significantly the influence of Financial Distress and Financial Risk Management on Value of the firm.
\end{abstract}

Keyword: Investment Decision, Capital Decision, Industry Performance, Macro Economic, Financial Risk Management, Financial Distress, Value Of The Firm, GCG

\section{INTRODUCTION}

Manufacturing industry sector is one of the important sector in national economic development. It supports the national economy since this sector contributes significantly to the economic growth of Indonesia (Darmawan , 2016). Indonesia is currently in transition to an agrarian-based economy to a semi-industrial economy in an effort to boost national economic growth. The pattern of subsistence economies relying on the primary sector is slowly shifting into an economy sustained by the manufacturing sector. Manufacturing industry sector is a fairly stable sector and become one of the support of the country's economy amid the uncertainty of the world economy with a positive growth rate. In addition , the manufacturing industry is a labor-intensive industry that absorbs a lot of labors . Based on data onto the Central Bureau of Statistics (BPS ) (Feb , 2017) in Indonesia the number of 
opened or unemployed workers reached 7.01 million people . This shows that there are still many workers that have no job to meet a decent life. Increased growth of manufacturing industry will be able to absorb labor in Indonesia so that will reduce the number of unemployment. The development of manufacturing industry in Indonesia suffered after the economic crisis in 1998 , where the growth of the manufacturing sector (21\%) was under Gross Domestic Product (23.7\%) (Basri , 2015 ) . Data onto the Central Bureau of Statistics (BPS ) of 2015 shows that the average growth of the manufacturing industry have decreased significantly , in the period of 2011-2014 the average growth was 5.3 while in 2015 , It dropped to 3.9 (CPM , 2015 )

The phenomenon of the decline in company growth, indicates that manufacturing companies is facing troubles and need to be attended, especially to the go public manufacturing companies. The decreasing growth indicates the declining of the company value that leads in lowering public investment confidence. Therefore, it is necessary to do an analysis to determine the factors affecting the value of the company / value of the firm. Based on the described background and to achieve the ultimate goal, the researcher assessed the significance of the influencing variables that is expected to affect the value of the company , consisting of Investment Decision , Capital Decision , Industry Performance, Macro Economic as endogenous variables, and Financial Risk Management, Financial Distress and Good Corporate Governance as moderating variables in manufacturing companies listed on the Indonesia Stock Exchange .

\section{Financial Management}

According to Van Horne and Warchowiz , Jr. (2014 : 20 ) it is said that financial management deals with the acquisition of assets, financing, and asset management based on some general purposes. Company management will deal with financial decisions such as introducing new products , the timing of investing in new assets , the timing of replacing the existing assets, the timing of borrowing money from banks, the timing of issuing shares or bonds, the timing of extending credit to customers, and how much cash should be maintained (Keown, Martin , Petty \& Scott Jr. 2005 : 4 ) . From the point of manager's view, the financial management decision is a decision related to (a ) the decision on the allocation of funds, both from inside and outside the company on various forms of investment, (b ) decision making of spending or financing investment, c ) dividend policy.

\section{Financial Decision}

Financial decisions are a decision that must be made by the company management to develop the business with the aim at maximizing the value of the company. According to Damodaran (2014) , there are three factors that are considered to maximize the value of the company namely investment decisions, funding decisions and dividend decisions . Internal financial decisions that have to be taken by the company according to Van Horne , Wachowicz $(2014: 2$ ) consists of 3 indicators namely investment decisions, funding decisions and dividend decisions. These three decisions will be reflected on the financial ratios associated with decision making in terms of investment and related to the company's ability to generate profits resulting from its investment, the ability of companies to utilize fixed assets , capital used , inventory and accounts receivable. Funding decision reflects the debt construction used by the company to fund its assets and indicates the company's ability to repay short-term debt secured by its current assets and cash position . The dividend decision is a decision that must be taken by the company to increase the prosperity of the shareholders. 


\section{Investment Decision}

The decision on investing is a decision that must be done carefully, because it involves the policy of the use of funds and returns received by the company or an investment decision on the asset in the expecting of obtaining a return greater than the minimum value that should be accepted . Determining the investment decisions are a very important decision, because it is closely related to the trust given by the community. As Warchowicz explains (2014:250) the current asset of manufacturing company typically accounts for more than half of the total assets. The larger the asset the faster the rate of returns / ROI but companies with smaller assets will disrupt means that the company will be getting difficulties in maintaining smooth operation.

\section{Financing Decision}

The company's funding decisions are inseparable from the investment policies set by the company. The funding decision is defined as a decision on the composition of funding chosen by the company (Hasnawati , 2005 ). According to Brigham , Houston , (2014 : 155 ) the determination of capital structure will involve the exchange of risk and return, the use of debt in larger quantities will increase the risk bore by the shareholders, but more debt in general will increase the estimated return on equity. The funding decision is a management decision on determining the optimal capital structure. So it won't disrupt the company's operations .

\section{Devidend Decision}

The dividend decision is a decision that must be taken by the company to increase the prosperity of the shareholders The value of a company formed by the indicator of stock market, is heavily influenced by investment opportunities. The signaling theory of the dividend is built based on the asymmetric information framework explains that as an insider in the firm, a manager in choosing dividend policy can be used as a means of information in relation to the prospect of the company William (1985) , Miller and Rock (1985 ) in Kusuma (2004).

\section{Industry Performance}

Performance is the result of work that is influenced by the structure and behaviour of the industry which the results can be identified by the amount of market control or the amount of profit of a company in an industry. Industrial Performance is a measure of a company that can describe the value of a company. The United Nations Industrial Development Organization (UNIDO ) developed a Competitiveness Industrial Performance (CIP) indicator which was then applied to measure the competitiveness of manufacturing industry sectors in 93 countries over the 1980-2000 period (Bapenas ). The size of the CIP indicator in Industrial Development Report 2004 consists of 4 (four ) main variables, namely (a ) value added per capital manufacturing industry, (b ) per capital manufacturing industry exports , (c) industrialization intensity as measured by the contribution of the manufacturing industry on GDP and the contribution of medium and high technology manufacturing industries to manufacturing sectors , (d) quality of exports measured by the contribution of manufactured exports to total exports and the contribution of medium and high technology manufacturing in the export value to the manufacturing industry .

\section{Macro Economics}

Economic growth can be defined as a development in an economy that causes goods and services produced in a society to increase (Sukirno, $2011: 9$ ). There are many indicators that can measure macro variables theoretically including political economic indicators . A fairly common indicator used to predict stock fluctuations is a variable directly controlled through monetary policy of / on a transmission mechanism through the financial market (Bank 
Pristiana, U., Ratnawati, T., \& Witjaksono, A. D. (2018). Investment Decision, Capital Decision, Industry Performance, Econimic Macros as Antecedent Variables of Financial Risk Management and Financial Distress Against Value of The Firm With GCG As a Variable Moderating For Manufacturing Companies Registered On The indonesian stock exchange. Archives of Business Research, 6(9), 147-163.

Indonesia , 2004 ) . These variables include Gross Domestic Product (GDP ) , Interest rate , inflation rate , and foreign exchange rate (Tandelilin , 1997) .

\section{Financial Risk Management / FRM .}

Risk management is a structured / methodological approach from / to managing uncertainties related to the threat (Mamduh , 2014) . The main objective of risk management is to minimize the potential losses arising from unexpected changes in the price of currency, credit , commodities, and equity. Anthony S and Marcia (2014 : 173 ) state that the main goal of the company is to benefit the owner. But these conditions are costly and there will be risks faced by the company. Annual Report of the go public company in the Financial Statement Note / CALK illustrated that the risks faced by manufacturing companies are risks associated with the condition of the company ie financial risk company or Financial Risk Management / FRM .

\section{Financial Distress}

Financial distress is a condition in which the company faces the problem of financial difficulties . Financial distress occurs when a company can not fulfill its obligations, especially in the case of debt payments (Ross, et al / , 1999 ). Companies in financial distress can be caused by various factors. These factors are (Ogden et al , $2003: 587$ ) : internal factors are factors that have a direct impact on the condition of financial distress and external factors are factors beyond the control of the company .

\section{Good Corporate Governance (GCG ) .}

Good Corporate Governance (GCG ) is a pillar of the market economy system , as it relates to public confidence to the company . Externally the company will be more trusted by investors . According to the Forum for Corporate Governance in Indonesia / FCGI (2001) , GCG is a set of rules governing relationships between shareholders, managers of companies, creditors , governments, employees and other internal and external stakeholders related to their rights and obligations or in other words a system that controls the company. The goal is to create added value of all stakeholders . Corporate governance mechanism aims to create added value of all stakeholders, so that there is no conflict between the agent and principal that impact on decreasing agency cost (Bodroastuti , 2009) . Good corporate governance mechanisms can be proxie with five variables according to a research (Black, et al , 2001), namely shareholder rights (shareholder rights ), board of directors, outside directors, audit committees and internal audit, and disclosure to investors .

\section{Value of the Firm}

Every company has a primary goal is to maximize the value of the company. The optimization of company values as it is the company's goal can be achieved through the implementation of the financial management function, whereby one financial decision will affect the other financial decisions and affect the value of the company (Fama and French , 1998 ), and the value of the company will be reflected from the stock market price (Fama , 1978). Salvatore in Purnama (2013) says that the main purpose of the company according to the theory value of the firm are to maximize the wealth or value of the company (value of the firm ). Van Horne and Warchowicz , Jr. (2014) state that the creation of corporate value is the maximization of after-tax returns (Earning After Taxes ). Maximizing the value of the company is very important to a company, because by maximizing the value of the company also means to maximize shareholder wealth that is the main goal of the company . 


\section{Population and Sample}

\section{RESEARCH METHODS}

The population of this study are all manufacturing companies listed on the Indonesia Stock Exchange. Based on IDX data onto 2016 the number of manufacturing companies listed on the Indonesia Stock Exchange accounted for 136 companies . Determination of sample used in this research is purposive sampling method, which is one technique of non-random sampling (non random sampling ) . Based on the determination of the criteria there are 40 companies selected to be analyzed .

\section{Definition of Concept}

1. Investment Decisions (X1) is a management decision on determining the right investment with the expectation of a return in accordance with the invested amount (Horne , Warchowicz, 2014)

2. Capital Decisions (X2 ) is a management decision on determining the optimal capital structure . So it will not disrupt the company's operations (Brigham , Houston , 2011)

3. Indutry Performance / Performance Industry (X3 ) is a measure of a company that can describe the value of a company (Fama , 1978)

4. Macro Economic / Macro Economy (X4 ) is a measure of the growth of a company determined by the rate of inflation, exchange rate and interest rate. (Damodaran, 2014)

5. Financial Risk Management / FRM (X5 ) is the amount of risk faced by the company by using the company's risk information contained in the company's financial statements (CALK Annual Report Go Public Manufacturing company .

6. Financial Distress (FD) (X6) is a condition where the company faces the problem of financial difficulties. Financial distress occurs when a company can not fulfill its obligations, especially in the case of debt payments (Ross, et al / , 1999).

7. Good Corporate Governance (GCG ) (X7) is a relationship of two aspects of governance structure that is the composition of directors and leadership structure of the directors (Daily and Dalton , 1994).

8. Value of the Firm / Value Company (Y) is depicted with the welfare of its owners that have a wealth of shares, the higher the value that will be reflected on / off the market price of its shares will provide prosperity for the owner (Fama , 1978)

\section{DATA ANALYSIS TECHNIQUE}

This research used two types of data analysis that is descriptive analysis and statistical analysis . Descriptive analysis was used to describe the results of research, while statistical analysis was used to prove the research hypothesis . Statistical analysis tool used is SEM-PLS with SmartPLS program .

\section{Evaluation Measurement (Outer) Model \\ Validity test}

An indicator is valid if it has a loading factor of more than 0.70 with a construct to be measured , however for the initial stage of development of a scale measuring, the loading values of 0.5 to 0.60 are considered sufficient (Chin , 1998 in Ghozali , 2015:74 ) . Smart PLS output for loading factor gives result as shown in Figure 1 of : 


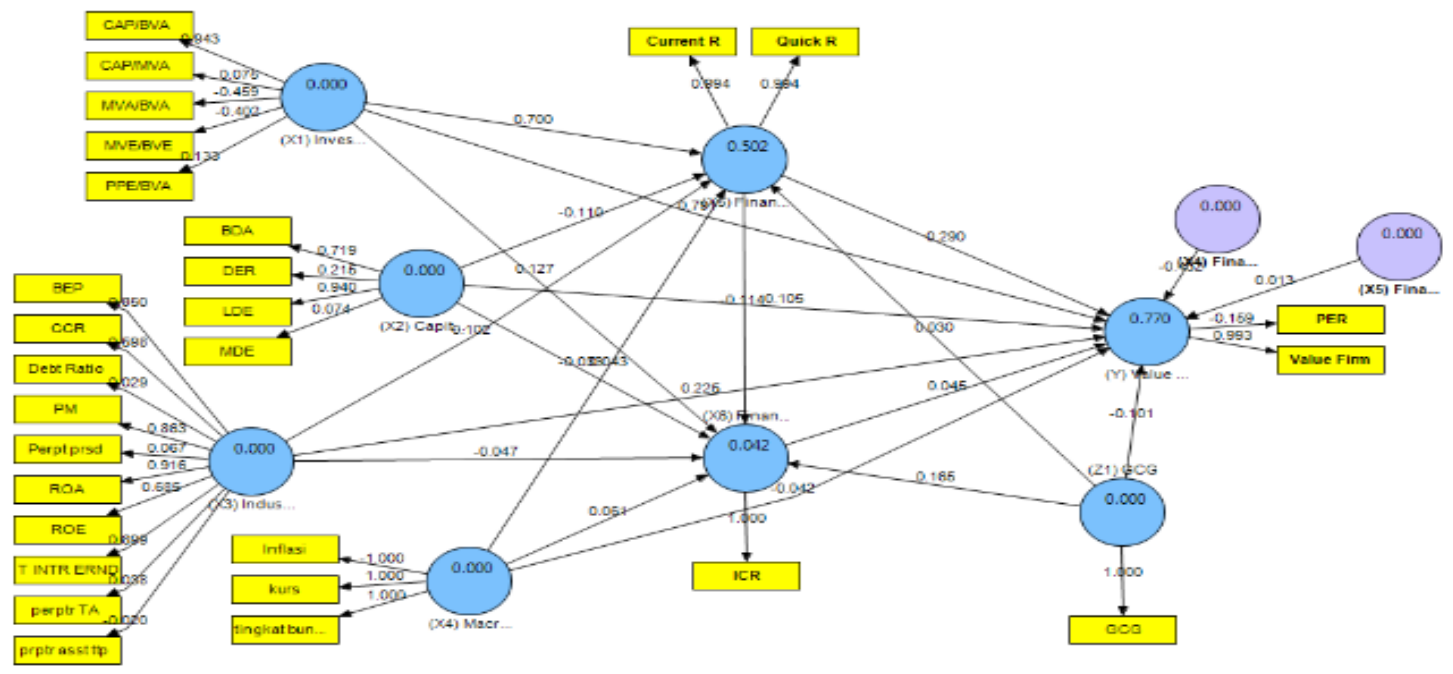

Figure 1. Smart PLS output for loading factor

The picture shows there are twelve indicators of research variables that have a loading factor smaller than 0.50. They are the ratio of PPE / BVA, CAP / MVA, MVA / BVA, MVE / BE as the indicator of the variable of Decision Investment, DER and MDE as the indicator variable of Capital Decision, Debt Ratio , Inventory Turnover, Total Asset Turnover, Fixed Asset Turnover as the indicator of Industry Performance variable, Inflation as the indicator of Macro Economic variable and PER as the Value of the Firm indicator. Indicators having a loading factor less than 0.70 or invalid are excluded from the model or not included in the next analysis phase. The analysis results after excluding twelve invalid indicators are shown in Figure 2 of :

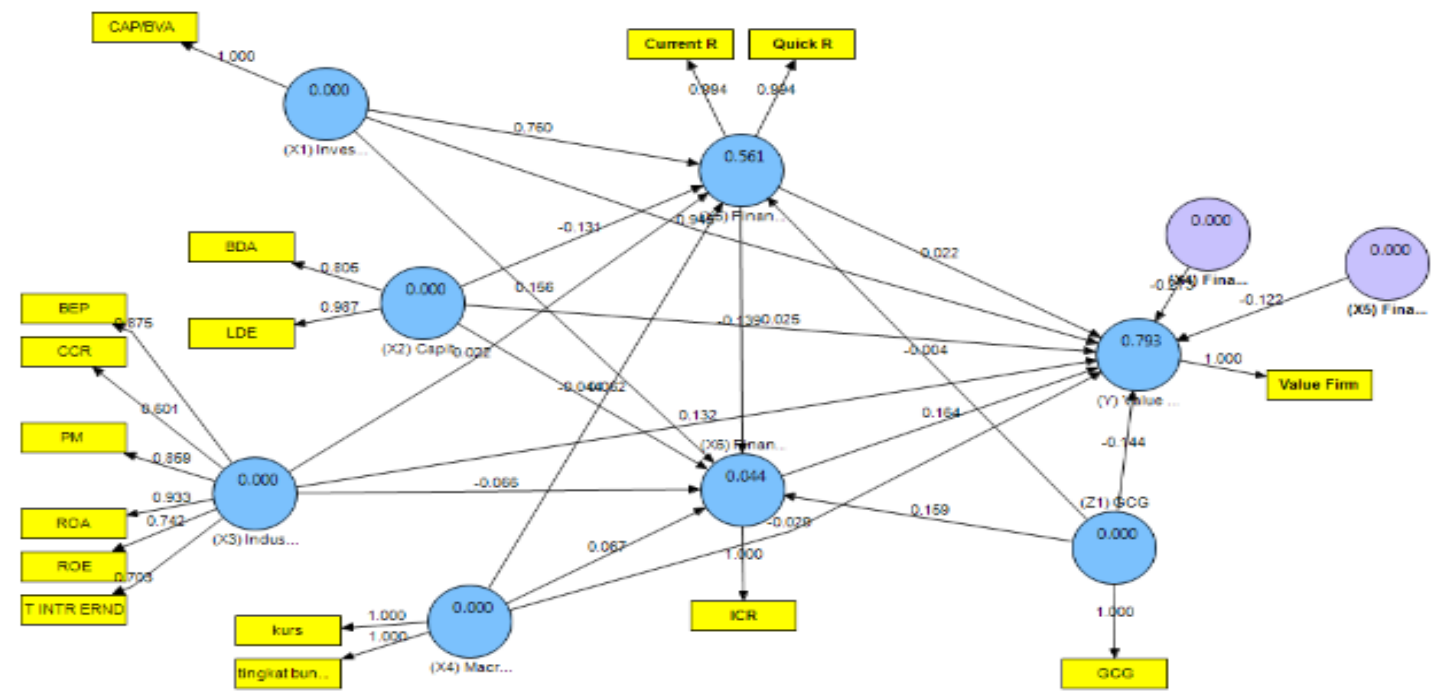

Figure 2. Smart PLS output

Reliability Test Reliability tests is done by checking the Composite Reliability value of the indicator block that measures the construct . Composite Reliability results are satisfactory if it has the value of 0.7 . Table 5.28 below is the value of Composite Reliability on output . 
Table 1 : Composite Reliability value

\begin{tabular}{|l|c|}
\hline & Composite Reliability \\
\hline (X1) Invesment Decision & 1.000000 \\
\hline (X2) Capital Decision & 0.894577 \\
\hline (X3) Industry Perfomance & 0.909051 \\
\hline (X4) Financial Risk Managament * (Z1) GCG & 0.989514 \\
\hline (X4) Macro Economic & 0.999956 \\
\hline (X5) Financial Distress * (Z1) GCG & 1.000000 \\
\hline (X5) Financial Risk Managament & 0.994018 \\
\hline (X6) Financial Distress & 1.000000 \\
\hline (Y) Value of the Firm & 1.000000 \\
\hline (Z1) GCG & 1.000000 \\
\hline
\end{tabular}

Resource composite Reliability Value Analysis with Smart PLS 2.0-2018

The table above shows that the value of composite reliability for all variables is above 0.7 indicating that all variables in the estimated model meets the criteria of discriminant validity .

\section{Structural Model Testing (Inner Model ) .}

The test of the structural model (inner model ) is performed after the estimated model meets the Outer Model criteria The result of testing for structural model (Inner model ) is as listed in Table 5.30 . The table shows that:

1. R-Square 0.793066 for Value of the Firm constructs means that Value of the Firm is able to explain the variance between Decision Investment, Capital Decision, Industry Performance, Macro Economic, Financial Risk Management, Financial Distress and GCG of 79.07 percent

2. R-Square 0.561332 for the construction of Financial Risk Management means that the Financial Risk Management is able to explain the variance between Decision Investment , Capital Decision , Industry Performance, Macro Economic , and GCG by 56.13 percent.

3. R-Square 0.044478 for Financial Distress constructs means that Financial Distress is able to explain the variance between Decision Investment, Capital Decision, Industry Performance, Macro Economic , Financial Risk Management and GCG of 4.45 percent .

Table 2. : R-Square

\begin{tabular}{|l|c|}
\hline & R Square \\
\hline (X1) Invesment Decision & \\
\hline (X2) Capital Decision & \\
\hline (X3) Industry Perfomance & \\
\hline (X4) Financial Risk Managament * (Z1) GCG & \\
\hline (X4) Macro Economic & \\
\hline (X5) Financial Distress * (Z1) GCG & \\
\hline (X5) Financial Risk Managament & 0.561332 \\
\hline (X6) Financial Distress & 0.044478 \\
\hline (Y) Value of the Firm & 0.793066 \\
\hline (Z1) GCG & \\
\hline
\end{tabular}

Resources R -Square with Smart PLS 2.0-2018

Proof the hypothesis in this research is done reviewing the significance influence between variables on coefficient parameter and significance value (t statistic ). In SmartPLS 2.0 it is done by looking at Algorithm Boostrapping report . Algorithm Boostrapping report obtained in this study is shown in Figure 3 and Table 3below : 


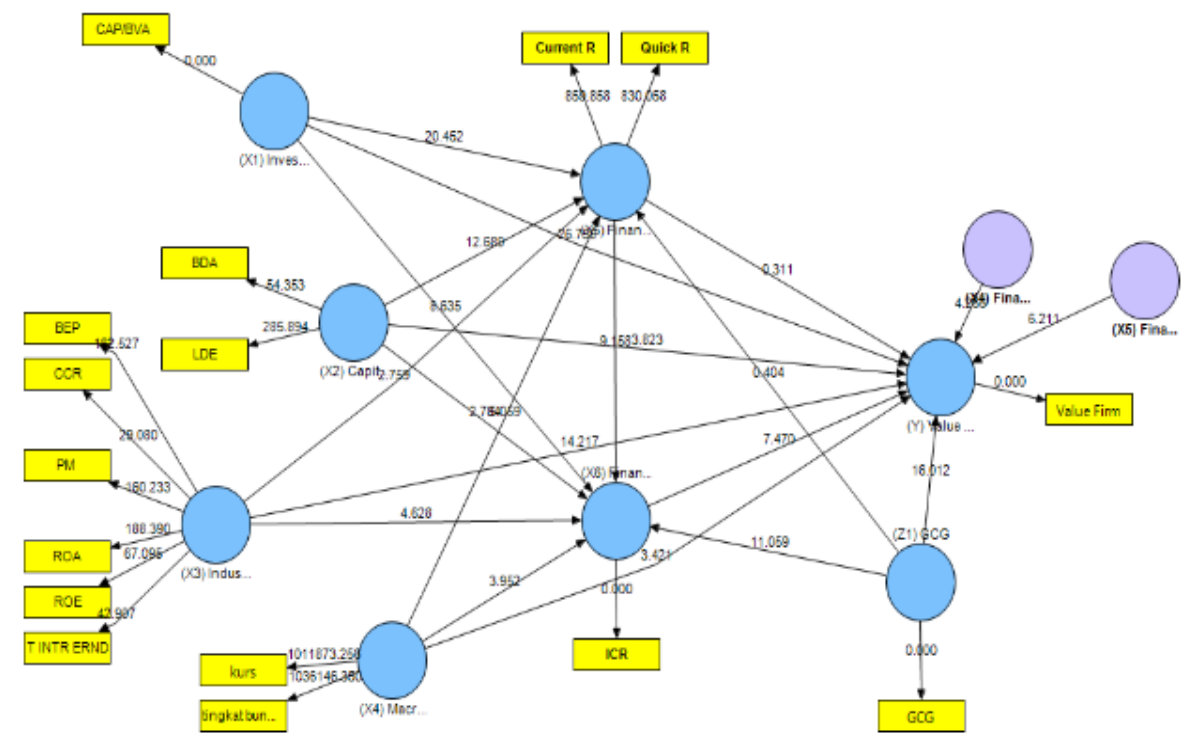

Figure 3: Boostrapping

Table 3: Path Coefficients ( Mean, STDEV, T-Value)

\begin{tabular}{|c|c|c|c|c|c|}
\hline & $\begin{array}{c}\text { Original } \\
\text { Sample } \\
\text { (O) }\end{array}$ & $\begin{array}{c}\text { Sample } \\
\text { Mean (M) }\end{array}$ & \begin{tabular}{|l|} 
Standard \\
Deviation \\
(STDEV)
\end{tabular} & $\begin{array}{l}\text { Standard } \\
\text { Error } \\
\text { (STERR) }\end{array}$ & $\begin{array}{l}\text { T Statistics } \\
\text { (0/STERR) }\end{array}$ \\
\hline (X1) Invesment Decision -> (X5) Financial Risk Managament & 0.760340 & 0.756210 & 0.037177 & 0.037177 & 20.451815 \\
\hline (X1) Invesment Decision -> (X6) Financial Distress & 0.156374 & 0.155499 & 0.018109 & 0.018109 & 8.634927 \\
\hline (Xl) Invesment Decision $>(\mathrm{Y})$ Value of the Firm & 0.945049 & 0.938863 & 0.035319 & 0.035319 & 26.757624 \\
\hline (X2) Capital Decision $\rightarrow(\mathrm{X} 5$ ) Financial Risk Managament & -0.131497 & -0.132633 & 0.010363 & 0.010363 & 12.688517 \\
\hline (X2) Capital Decision $\rightarrow(\mathrm{X} 6$ ) Financial Distress & -0.044114 & -0.045062 & 0.015847 & 0.015847 & 2.783785 \\
\hline (X2) Capital Decision $\rightarrow(\mathrm{Y})$ Value of the Firm & 0.025112 & 0.025367 & 0.006568 & 0.006568 & 3.823139 \\
\hline (X3) Industry Perfomance $>$ (X5) Financial Risk Managament & 0.022195 & 0.023658 & 0.008045 & 0.008045 & 2.758785 \\
\hline (X3) Industry Perfomance - $>$ (X6) Financial Distress & -0.065640 & -0.063628 & 0.014183 & 0.014183 & 4.628152 \\
\hline (X3) Industry Perfomance $\rightarrow(Y)$ Value of the Firm & 0.131519 & 0.133577 & 0.009251 & 0.009251 & 14.217352 \\
\hline $\begin{array}{l}\text { (X4) Financial Risk Managament * }(\mathrm{Zl}) \mathrm{GCG}>(\mathrm{Y}) \text { Value of } \\
\text { the Firm }\end{array}$ & 2610 & 2841 & 0.064054 & 154 & 4 \\
\hline (X4) Macro Economic $\rightarrow$ (X5) Financial Risk Managament & 0.061954 & 0.061659 & 0.012247 & 0.012247 & 5.058853 \\
\hline (X4) Macro Economic $\rightarrow(\mathrm{X} 6)$ Financial Distress & 0.066628 & 0.064495 & 0.016860 & 0.016860 & 3.951814 \\
\hline$(\mathrm{X} 4)$ Macro Economic $\rightarrow(\mathrm{Y})$ Value of the Firm & -0.029478 & -0.030213 & 0.008616 & 0.008616 & 3.421312 \\
\hline (X5) Financial Distress * (Z1) GCG $\rightarrow(Y)$ Value of the Firm & -0.121728 & -0.121459 & 0.019599 & 0.019599 & 6.210832 \\
\hline (X5) Financial Risk Managament $\rightarrow(\mathrm{X} 6)$ Financial Distress & -0.138958 & -0.139835 & 0.015174 & 0.015174 & 9.157940 \\
\hline (X5) Financial Risk Managament $>(\mathrm{Y})$ Value of the Firm & 0.022191 & 0.047212 & 0.071311 & 0.071311 & 0.311182 \\
\hline (X6) Financial Distress $\rightarrow(\mathrm{Y})$ Value of the Firm & 0.163587 & 0.164187 & 0.021900 & 0.021900 & 7.469651 \\
\hline (Zl) GCG $>$ (Xs) Financial Risk Managament & -0.003940 & -0.005014 & 0.009761 & 0.009761 & 0.403605 \\
\hline$(\mathrm{Z} 1) \mathrm{GCG} \rightarrow(\mathrm{X} 6)$ Financial Distress & 0.158834 & 0.157500 & 0.014362 & 0.014362 & 11.059066 \\
\hline (Zl) GCG $>$ (Y) Value of the Firm & -0.144209 & -0.143565 & 0.009006 & 0.009006 & 16.011973 \\
\hline
\end{tabular}

Resouces Path Coefficients with Smart PLS 2,0-2018

\section{Effect of Investment Decision on Financial Risk Management .}

The result of analysis shows that Investment Decision has significant effect of Financial Risk Managament as evidenced by T-statistic value of $20.451815>1.96$. The original sample estimate of 0.760340 indicates that the direction of the relationship between Investment Decision to Financial Risk Managament had a positive influence on. The effect of investment decision on financial risk management of manufacturing company of research sample had a positive on, that is , the bigger the investment is done by company , the greater the financial risk faced by the company, the smaller the investment made by the research sample manufacturing company, the smaller the financial risks faced by the company . The results of this study do not support the theory saying that the investment_decision has a negative effect on financial risk management. This happens because according to the theory, when the 
investment decision decreases then financial risk management increase . The obtained reality shows that during the period of financial risk management research faced by manufacturing companies, research sample decreased, because the CR trend decreased by 0.2 percent while QR increased by 2.9 percent, so that the average increased. The results of this study can not be compared with the results of previous research, because the previous research did not examine the effect of financial risk management on financial risk management .

\section{The Effect of Investment Decision on Financial Distress}

The result of analysis shows that Investment Decision has significant effect of / on Financial Distress as evidenced by T-statistic value of 8.634927> 1.96 . The original sample estimate of 0.156374 shows that the direction of the relationship between Investment Decision to Financial Distress had a positive influence on. The effect of influence of investment decision on financial distress of manufacturing company, as the research sample, is nondirectional, meaning that the better investment decided by manufacturing company of research sample hence the big of incapability to pay obligation (financial distress ) company . The results of this study do not support the theory that the investment decision has a negative effect on financial distress. This happens because according to the theory of investment decision, that is not good will cause financial incompetence (financial distress ) company will increasingly. The facts obtained show that during the period of financial distress research faced by manufacturing companies research samples decreased, because the trend of ICR on average increased by 0.7 percent. (The results of the study can not be compared with the results of previous research, because previous research did not examine the effect of investment decision on financial distress .

\section{The Effect of Investment on Value of the Firm}

The result of analysis shows that the Decision Investment has significant effect of / on Value of the Firm which is proved by T-statistic value of $26.757624>1.96$. The original sample estimate of 0.945049 indicates that the direction of the relationship between Investment Decision to Value of the Firm had a positive influence on. The influence of investment decision on Value of the Firm manufacturing company research sample is unidirectional, meaning the better the investment decided by the company manufacturing research sample then the higher the Value of the Firm. The results of this study support the theory that the investment decision has a positive effect on the firm's value. This happens because according to theory, investment decision is getting better then the Value of the Firm is also increasing. The facts obtained show that during the study period the firm's value faced by the manufacturing company of the research sample has increased by 10.79 percent. The results support research conducted by Fenandar, and Raharja (2012) which shows that investment decisions have a positive and significant impact on corporate value .

\section{Influence of Capital Decision to Financial Risk Management .}

The result of analysis shows that Capital Decision has significant effect of Financial Risk Managament as evidenced by T-statistic value of T-statistic equal to 20.451815>1,96 . The original sample estimate of - 0.131497 shows that the relationship between Capital Decision to Financial Risk Managament is opposite. The direction of influence of capital decision on financial risk management of manufacturing company of research sample is opposite direction , meaning lower funding determined by manufacturing company of research sample hence higher financial risk management. The results of this study support the theory that capital management has a negative effect on financial risk management. This happens because according to theory, if the capital decision are getting better then financial risk management also decreased. The reality obtained shows that during the period of financial risk management research faced by manufacturing companies research samples decreased, 
Pristiana, U., Ratnawati, T., \& Witjaksono, A. D. (2018). Investment Decision, Capital Decision, Industry Performance, Econimic Macros as Antecedent Variables of Financial Risk Management and Financial Distress Against Value of The Firm With GCG As a Variable Moderating For Manufacturing Companies Registered On The indonesian stock exchange. Archives of Business Research, 6(9), 147-163.

because the CR trend decreased by 0.2 percent while QR has increased 2.9 percent, so that the average increase . compared with the results of previous research, because previous research did not examine the influence of capital decisions on financial risk management

\section{Influence of Capital Decision to Financial Distress .}

The result of analysis shows that Capital Decision has significant effect of / on Financial Distress as proved by T-statistic value of $2.783785>1.96$. The original sample estimate of 0.044114 indicates that the direction of the relationship between Capital Decision to Financial Distress is opposite. The direction of the influence of the capital decision to the financial distress of the manufacturing enterprise of the research sample is in the opposite direction , that is, the lower the financing structure decided by the research sample manufacturing company the greater the inability to pay the financial distress and vice versa if the higher funding structure decided by companies manufacturing research samples hence the inability to pay obligations (financial distress ) company getting smaller. The results of this study support the theory that capital management has a negative effect on financial distress. This happens because according to theory, if the better capital decision will cause financial incompetence (financial distress) company will decrease. The facts obtained show that during the period of financial distress research faced by manufacturing companies research samples decreased, because the trend of ICR on average increased by 0.7 percent. The results of the study can not be compared with the results of previous research, because previous research did not examine the influence of capital decisions on financial distress .

\section{Influence of Capital Decision to Value of the Firm .}

The result of analysis shows that Capital Decision has significant effect of Value of the Firm which is proved by T-statistic value of 3.823139> 1.96. The value of the original sample estimate of 0.025112 indicates that the direction of the relationship between Capital Decision to Value of the Firm had a positive influence on. The direction of influence of capital decision to firm firm value of manufacturing research sample is unidirectional , meaning better financing structure determined by manufacturing company of research sample hence higher Value of the Firm . The results of this study support the theory that capital management has a positive effect on firm value. This happens because according to theory, the better capital decisions the better Value of the Firm also . The facts obtained show that during the study period the firm's value faced by the manufacturing company of the research sample has increased by 10.79 percent. The results support the research conducted by Nirmala (2010) , Hermuningsih (2013 ) , Obaid (2016) which states that the funding structure has significant effect on the firm's value, but does not support the research conducted by Fenandar, and Raharja (2012 ) no effect on the Value of the Firm .

\section{Influence of Industry Perfomance to Financial Risk Management .}

The result of analysis shows that Industry Perfomance has significant effect of Financial Risk Managament as evidenced by T-statistic value of $2.758785>1.96$. The original sample estimate of 0.022195 shows that the direction of the relationship between Industry Perfomance to Financial Risk Managament is the same direction. The direction of the influence of the performance industry towards the financial risk management of manufacturing companies research sample had a positive influence on, meaning that the better performance industry produced by manufacturing companies research samples, the higher the financial risk management. The results of this study do not support the theory that performance industry has a negative effect on financial risk management. This happens because theoretically, the lower the performance industry the financial risk management is lower. The reality obtained 
shows that during the period of financial risk management research faced by manufacturing companies research sample decreased, because the CR trend decreased by 0.2 percent while QR increased by 2.9 percent, so that the average increase. The results of the study can not be compared with the results of previous research, because previous research did not examine the influence of the performance industry against financial risk management.

\section{Influence of Industry Perfomance to Financial Distress .}

The result of analysis shows that Industry Perfomance has significant effect of Financial Distress which is proved by T-statistic value of 4.628152> 1.96. The original sample estimate of - 0.065640 indicates that the direction of the relationship between Industry Perfomance to Financial Distress is opposite. The direction of the influence of the industry performance on the financial distress of the manufacturing company's research sample is in the opposite direction, meaning that the higher the performance industry obtained by the research sample manufacturing company, the less financial liability. The results of this study support the theory that performance industry has a negative effect on financial distress. This happens because according to theory, the higher the performance industry will cause financial distress the company will decrease. The facts obtained show that during the period of financial distress research faced by manufacturing companies research samples decreased, because the trend of ICR on average increased by 0.7 percent. The results of the study can not be compared with the results of previous research, because previous research did not examine the influence of the performance industry against financial distress .

\section{Influence of Industry Perfomance to Value of the Firm .}

The result of analysis shows that Industry Perfomance has significant effect of Value of the Firm which is proved by T-statistic value of $14.217352>1.96$. The original sample estimate of 0.131519 indicates that the direction of the relationship between ) . Industry Performance against Value of the Firm is unidirectional. The direction of the influence of the company's performance toward the firm's firm's firm's value of the research is unidirectional , meaning that the better the industry performance produced by the research sample manufacturing company the higher the firm's value. The results of this study support the theory that the performance industry has a positive effect on the firm's value. This happens because according to theory, if the performance industry the better the Value of the Firm also the better. The facts obtained show that during the study period the firm's value faced by the manufacturing company of the research sample has increased by 10.79 percent. The results of the study can not be compared with the results of previous research, because previous research did not examine the influence of the performance industry against the Value of the Firm .

\section{Effect of Macro Economic on Financial Risk Management .}

The result of analysis shows that Macro Economic has significant effect of Financial Risk Managament which is proved by T-statistic value of 5.058853> 1.96 .The original sample estimate of 0.061954 shows that the direction of the relationship between Macro Economic to Financial Risk Managament is the same direction. The direction of influence of macro economic to financial risk management of manufacturing companies research samples is unidirectional, meaning the lower macro economic policy then the lower the financial risk management. The results of this study do not support the theory that macro economic has a negative effect on financial risk management. This happens because according to theory, if macro economic policy is lower then financial risk management is also lower. The reality obtained shows that during the period of financial risk management research faced by manufacturing companies research sample decreased, because the CR trend decreased by 0.2 percent while QR increased by 2.9 percent, so that the average increase . 
Pristiana, U., Ratnawati, T., \& Witjaksono, A. D. (2018). Investment Decision, Capital Decision, Industry Performance, Econimic Macros as Antecedent Variables of Financial Risk Management and Financial Distress Against Value of The Firm With GCG As a Variable Moderating For Manufacturing Companies Registered On The indonesian stock exchange. Archives of Business Research, 6(9), 147-163.

\section{Effect of Macro Economic on Financial Distress .}

The result of analysis shows that Macro Economic has significant effect of Financial Distress which is proved by T-statistic value of 3.951814> 1.96 . The original sample estimate of 0.066628 indicates that the direction of the relationship between Macro Economic to Financial Distress is unidirectional. The direction of the influence of macro economic to financial distress manufacturing companies research sample is unidirectional, meaning that the better macro economic hence the higher the condition of the inability to pay obligations (financial distress ) company. The results of this study support the theory that macro economic positively affects / affected the financial distress . This happens because according to theory , if the macro economic the better will cause financial incompetence (financial distress ) company will be higher. The facts obtained show that during the period of financial distress research faced by manufacturing companies research sample has increased, because the trend of ICR on average increased by 0.7 percent. The results can not be compared with the results of previous research, because previous research did not examine the effect of macro economic to financial distress .

\section{Effect of Macro Economic on Value of the Firm .}

The result of analysis shows that Macro Economic has significant influence of Value of the Firm Managament which is proved by T-statistic value of 3.421312> 1.96 . The original value of sample estimated is -0.029478 which show that the direction of the relationship between Macro Economic to Value of the Firm is opposite. The direction of influence of macro economic to firm firm's value of manufacturing research sample is opposite direction, meaning better macro economic condition then lower Value of the Firm. The results of this study do not support the theory that macro economic positively affects the Value of the Firm. This happens because according to theory, if the macro economic are declining then the Value of the Firm is also getting better. The facts obtained show that during the study period the firm's value faced by the manufacturing company of the research sample has increased by 10.79 percent . The results of this study support research conducted by Frimpong, JM (2009) which concludes that macroeconomic (exchange rate , consumer price index , money supply, and interest rate ) have a negative impact on stock prices and stock returns in Ghana stock exchange. However , the results of this study do not support research conducted by Sandhi (2014) indicating that macro economy has positive and significant effect of / on Value of the Firm , Levy (2006 ) found that index positively correlated to stock return in Palestinian stock exchange, Imron (1990 ) a causal relationship was found between macroeconomic indicators and stock prices , Tirapat and Nittayagasetwat (1999) which concluded that macroeconomic conditions were a critical indicator that caused the company to experience a corporate financial crisis in Thailand.

\section{Influence of Financial Risk Management to Financial Distress .}

The results of the analysis show that the Financial Risk Managament has no significant effect on Value of the Firm proved by the T-statistic value of $0.311182<1.96$. The original sample estimate value of 0.022191 indicates that the direction of the relationship between Financial Risk Managament to Value of the Firm is unidirectional. The direction of the influence of financial risk management on the financial distress of the manufacturing company in the research sample is opposite direction, meaning that the higher the financial risk management produced by the research sample manufacturing company, the lower the company's financial distress. The results of this study do not support the theory that financial risk management has a positive effect on financial distress. This happens because according to theory, if financial risk management is low then financial risk management is also low . The facts 
obtained show that during the period of financial distress research faced by manufacturing companies research samples decreased, because the trend of ICR increased by 0.7 percent , The results can not be compared with the results of previous research, because previous research did not examine the influence of financial risk management to financial distress.

\section{Influence of Financial Risk Management to Value of the Firm .}

The results of the analysis show that the Financial Risk Managament has significant effect on Financial Distress as evidenced by the T-statistic value of $9.157940>1.96$. The original sample estimate of -0.138958 shows that the direction of the relationship between Financial Risk Managament to Financial Distress is opposite . The direction of the influence of financial risk management to firm firm's value of manufacturing research sample is unidirectional, meaning that the higher the financial risk management the higher the firm's value. The insignificant effect of financial risk management on the firm's value is due to the decrease in financial risk management of the company during the period of research, due to the fact that CR trend has decreased by 0.2 percent although $\mathrm{QR}$ has increased by 2.9 percent .

\section{Effect of Financial Distress on Value of the Firm .}

The results of the analysis show that the Financial Distress significantly influences the Value of the Firm as evidenced by the value of T-statistics of 7.469651> 1.96. The original sample estimate of 0.163587 indicates that the direction of the relationship between Financial Distress to Value of the Firm is unidirectional. The direction of the influence of financial distress to firm firm's firm's value of manufacturing is unidirectional, meaning that the higher the financial distress condition of the firm the higher the firm's value. The results of this study do not support the theory that states that financial distress negatively affected the Value of the Firm . This happens because according to theory, if the higher the financial distress condition the higher the firm's value is also the better. The facts obtained show that during the study period the firm's value faced by the manufacturing company of the research sample has increased by 10.79 percent. The results can not be compared with the results of previous research, because previous research did not examine the effects of financial distress on the firm's value.

\section{The Influence of Good Corporate Governance to Financial Risk Management .}

The results of the analysis show that Good Corporate Governance has no significant effect on the Financial Risk Managament as evidenced by the T-statistic value of $0.403605<1.96$. The original sample estimate of - 0.003940 shows that the direction of the relationship between Good Corporate Governance to Financial Risk Managament is opposite. The direction of the influence of good corporate governance of the financial risk management of manufacturing companies in the research sample is unidirectional, meaning the lower the involvement in management (good corporate governance) , the lower the financial risk management. The lack of significance of GCG to FRM is due to the fact that during the research period there is a decrease in quality of corporate governance which is indicated in spite of an increase in managerial awareness, but the increase in share ownership is only owned by the managerial manager. Should increase the ownership of shares conducted by external parties company

\section{The Influence of Good Corporate Governance to Financial Distress .}

The result of the analysis shows that Good Corporate Governance has significant effect of Financial Distress as proved by T-statistic value of 11.059066> 1.96 . The original sample estimate of 0.158834 indicates that the direction of the relationship between Good Corporate Governance to Financial Distress is had a positive influence on . The direction of the influence of good corporate governance of the financial distress of the research sample manufacturing company is had a positive influence on, the lower the management of good corporate governance, the lower the inability to pay the company's financial distress. The results of this 
study do not support the theory that good corporate governance has a negative effect on financial distress. This happens because according to theory, if good corporate governance is higher will cause the lower the financial disability (financial distress ) company . The reality obtained shows that during the period of financial distress research faced by manufacturing companies research samples decreased, because the ICR trend on average increased. The results of this study support the research conducted by Emrinaldi (2007) which concluded with the increase in managerial ownership will be able to push down the potential for financial distress . Wardhani (2006) does not support the results of research state the greater the number of directors the higher the possibility of companies experiencing pressure conditions finance. The Daily \& Dalton study (1994 ) concludes that there is indeed a significant relationship between the composition of the directors and the leadership structure of the directors with the possibility of the company going bankrupt. The Iramani (2007) studied concluded that the partial ownership structure can not be used as a predictor in the financial distress model .

\section{The Influence of Good Corporate Governance to Value of the Firm .}

The result of analysis shows that Good Corporate Governance has significant effect of Value of the Firm which is proved by T-statistic value of 16.011973> 1.96. The original sample estimates value of -0.144209 which show that the direction of the relationship between Good Corporate Governance to Value of the Firm is opposite direction. The direction of the influence of good corporate governance of the firm's firm's value of manufacturing research is in opposite direction, meaning that the higher the managerial (good corporate governance ) the lower the firm's value. The results of this study support the theory that the good corporate governance negatively affects the Value of the Firm. This happens because according to theory , if good corporate governance is lower then the Value of the Firm is also increasing . The facts obtained show that during the study period the firm's value faced by the manufacturing company of the research sample has increased by 10.79 percent . The results of this study support research conducted by Ruan, Tian and Ma (2011) which concludes that there is a negative relationship between managerial ownership and firm value, but does not support research by Short and Keasey (1999) in Emrinaldi , (2007) the linear relationship between managerial ownership and firm value and Rustendi and Jimmi's research (2008) shows that partially managerial ownership has no effect on firm value . Black , Jang , and Kim (2001) also show that there is a positive correlation between GCG and firm value .

\section{Good Corporate Governance moderated the influence of Financial Risk Management to Value of the Firm .}

The result of analysis shows that Good Corporate Governance as a moderator of relationship between Financial Risk Managament with Value of the Firm is a significant influence as evidenced by the T-statistics of $4.255963>1.96$. The original sample estimate of -0.272610 indicates that Good Corporate Governance as a moderator of the relationship between Financial Risk Managament and Value of the Firm is the same direction. The results of this study indicate that good corporate governance is able to weaken the influence of financial risk management to Value of the Firm . The results of the study can not be compared with the results of previous research, because previous research did not examine the moderation of influence of financial risk management to Value of the Firm . 


\section{The Influence of Good Corporate Governance as a moderator of the relationship between Financial Distress and Value of the Firm .}

The result of the analysis shows that Good Corporate Governance as a moderator of the relationship between Financial Distress and Value of the Firm is a significant influence as evidenced by the value of T-statistics of 6.210832> 1.96. The original sample estimate of 0.121728 indicates that Good Corporate Governance as a moderator of the relationship between Financial Distress with Value of the Firm is the same direction. The results of this study indicate that good corporate governance is able to weaken the influence of financial distress on the firm's value. The results can not be compared with the results of previous research, because previous research did not examine about the moderation of the influence of financial distress on the firm's value.

\section{CONCLUSION}

1. Investment decisions have a significant effect on the financial risk management of manufacturing companies .

2. Investment decisions have a significant effect on the financial distress of manufacturing companies .

3. Invesment decision has a significant effect on the value of the research company's manufacturing sample .

4. Capital decisions have a significant effect on the financial risk management of manufacturing companies .

5. Capital decisions have a significant effect on the financial distress of manufacturing companies research samples .

6. Capital decisions have a significant effect on the value of the firm of manufacturing research sample.

7. Industry performance has a significant effect on the financial risk management of manufacturing companies research samples .

8. Industry performance has a significant effect on financial distress manufacturing company sample research Industry performance has a significant effect on the value of the firm of manufacturing research sample.

9. Macro economic significant effect on the financial risk management of manufacturing companies research samples .

10. Macro economic has a significant effect on the financial distress of manufacturing companies research samples .

11. Macro economic significant effect on the value of the firm firm manufacturing research samples / sampled .

12. Financial risk management has a significant effect on the financial distress of manufacturing company of research sample .

13. Financial risk management has no significant effect on the value of the firm of manufacturing research sample .

14. Financial distress has a significant effect on the value of the firm of manufacturing research sample .

15. Good corporate governance has no significant effect on financial risk management of manufacturing company of research sample .

16. Good corporate governance has a significant effect on the financial distress of manufacturing company of research sample .

17. Good corporate governance has a significant effect on the value of the firm of manufacturing research sample.

18. Good corporate governance moderates the influence of financial risk management on firm firm's value of manufacturing research samples / sampled . 
Pristiana, U., Ratnawati, T., \& Witjaksono, A. D. (2018). Investment Decision, Capital Decision, Industry Performance, Econimic Macros as Antecedent Variables of Financial Risk Management and Financial Distress Against Value of The Firm With GCG As a Variable Moderating For Manufacturing Companies Registered On The indonesian stock exchange. Archives of Business Research, 6(9), 147-163.

19. Good corporate governance moderates the influence of financial distress on the firm's firm's value of manufacturing research samples .

\section{LIMITATIONS}

In this research, the researcher feels still not able to fully answer the problems related to the research variables used are investment decision, capital decision, industry performance, macro economic , financial risk management, good corporate governance, financial distress and Value of the Firm. However, with this limitation, the researcher hopes that this research can be used as reference material for the next researcher and contribute to the next study. The limitation of the research is the incomplete data onto the financial report on manufacturing companies listed on the BEI which is the population of this study, so that the members of the population are not included in the process of determining the research sample .

\section{Reference}

Anthony S, Marcia. 2014. Financial Institutions Management: A Risk Management Approach, Eighth edition, Mc Graw-Hill International Edition.

Baspenas, 2004. Industrial Development Report.

Bapenas, Decree No. Kep-29 / PM / 2004 dated September 24, 2004

Bappenas, 2004, Increasing Daylight Manufacturing Industry,

Basri, faisal: https://faisalbasri.com/2015/08/30/ stimulate-industrialization- to support growth-quality Central Bureau of Statistics, 2017 "Manufacturing Industry Directory"

Bodroastuti, Tri.2009. The Influence of Corporate Governance Structure to Financial Distress. Journal of Economics of STIE Widya Manggala.

Brigham, E.F. and Houston, 2014. Essentials of Financial Management (Translation) book 1, edition 11. Salemba Empat. Jakarta.

Daily, Catherine M., and R. Dalton. 1994. Bankruptcy and Corporate Governance: The Impact of Board Composition and Structure. The Academy of Management Journal. December, Vol. 37 (6), 1603-1617.

Damodaran, Aswath (2014). Applied Corporate Finance, Fourth Edition, New York Stren School of Business: John Willey \& Sons.

Darmawan, Arief, 2016 "Development of Manufacturing Industry in Indonesia in 2015-2016" November 2016.www.academia.ecu

Emrinaldi. 2007. Analysis of the Influence of Corporate Governance Practices on Financial Distress: An Empirical Study. Journal of Business and Accounting, Vol. 9, No. 1, h. 88-104

Fama, Eugene F.1978. The effect of a Firm's Investment and Financing Decision on the Walfaare of its Security Holders. The American Economic Review, Vol 68 No.3 June

Fama and French .1998. The Institutional Evidence. The Journal of Finance. Vol LIII. No.6. December.

Frimpong Joseph Magnus. 2006 Modeling and Forecasting Volatility of Returns on the Ghana Stock Exchange Using Garch Models. American Journal of Applied Sciences 3 (10): 2042-2048

Gany Ibrahim Fenandar, Surya Raharja 2012. Influence of Investment Decisions, Funding Decisions, and Dividend Policies Against Corporate Values Diponegoro Journal of Accounting Volume 1, Number 2, Year 2012, Pages 1-10

Ghozali, Imam 2015, Partial Least Squares: Concepts, Techniques and Applications Using the SmartPLS Program. Semarang: Issuing Board of Diponegoro University.

Hasnawati, S. 2005. Implications of Investment Decisions, Funding, and Dividends Against Corporate Value Public on the Jakarta Stock Exchange. Entrepreneur: No.09 / Th XXXIX. September 2005: 33-41.

IGAK. S Purnama, IGB.Wiksuana, IKetut Mustanda 2013. The Influence of Macro Economic Performance on Industry Performance and Corporate Financial Performance and the Stock Return of Banking Companies. Journal of Management, Business Strategy, and Entrepreneurship Vol. 7, No. 1, February. 
Imron, Ali, Kashif Ur Rehman, Ayse Kucuk Yilmaz, M Aslam Khan, Hasan Afzal, 2010. "Causal Relationship between macro-economical indicators and stock exchange prize in Pakistan", African journal of Business Management, April.

Iramani, 2007, Analysis of Ownership Structure and Relative Industrial Ratio as Predictors in the Model of Financial Difficulties, Business Journal and Management. STIE Perbanas Surabaya

Keown, Martin, Petty \& Scott Jr, 2005: "Financial Management: Principle and Aplications, 10th Edition. Pearson ISBN13: 978013145065

Ruan, Tian and Ma (2011), Managerial Ownership, Capital Structure and Firm Value: Evidence from China's Civilian-run Firms, Australian Accounting, business and Finance. Vol 3.

Sri Hermuningsih (2013). "Influence of Profitability, Growth Opportunity, Capital Structure Against Corporate Values in Public Companies in Indonesia that fall into the category of LQ 45" Bulletin of Monetary Economics and Banking, October 2013

Sukirno, Sadono, 2011. "Macro Economy, Prngantar Theory" Third edition, PT. Raja Grafindo Persada, Jakarta.

Tamir Levy. 2009 The Oslo Index and Stock Returns. International Research Journal of Finance and Economics ISSN 1450-2887 Issue 23.

Tandelilin, Eduardus 1997, Datermin ants of Systematic Risk: The Experience of Some Indonesian Common Stock, Yogyakarta: BPFE.

Tirapat, S. and Nittayagasetwat, A. 1999. An Investigation of Thai Listed Firms' Financial Distress Using Macro and Micro Variables. Multinational Finance Journal 3: 103-125.

Van Home J, J M. Warchowicz, Jr., 2013. Fundamental Of Financial Management, (translation) book 1, edition 13, Salemba Empat

-------, "Capital Market Directory (2010-2014). Bank Indonesia

"IDX Indonesia Stock Exchange" 